\title{
Just Listening to Sarah Dessen
}

$t$ was the second week of school, and I had just brought my copy

of Sarah Dessen's Just Listen to my classroom to put on my shelves. As we waited for first hour to begin, Callie, a bright-eyed $7^{\text {th }}$ grader, rushed toward me, explaining that she had just seen the list of recommended books in my classroom newsletter and had noticed the newest Sarah Dessen title. Did I have it? Reaching for it on my shelves, I shared with her that I not only had the book, but I would have the privilege of interviewing and meeting Sarah in Nashville at the ALAN convention. From that moment, Callie and I shared a bond that went beyond the student-teacher bond: it was a bond shared by avid readers.

August, September, October and, finally, November were peppered with Callie's questions. Would I ask her this? How about that? Could I get an autograph? Could I please take her with me? And Callie's enthusiasm was not unique. When it came time to actually write the review of Just Listen, I approached student after student in search of my copy. I cannot say I was surprised. Similar reactions to Sarah's books have occurred throughout my career as a teacher and an advocate of YA lit. Sarah Dessen understands the fears and triumphs of young girls, and it is because of this that I was interested in learning more about not just her books, but her approach to writing.

While this interview was conducted via email, I had a chance to meet with Sarah at both the ALAN reception and at the conference, where she spoke about romance and YA literature. As expected, she was easy to talk to, and shared insights into her career as an author:

TAR: I first discovered your work when I was teaching sophomore English in 2000. When my librarian recommended Dreamland to me, I immediately read it and fell in love with Caitlin's story. My students quickly began passing it around, and I'm not sure it ever went back on the library's shelves that year. Then, a couple years ago, I switched to seventh grade English, and figured I would have to discover new authors that would appeal to a younger audience. To my surprise, these younger girls embraced your characters just as quickly, and today, I'm not sure which girl has my copy of Just Listen. Why do you think your characters speak to such a wide range of age groups?

SD: I like to think that it's because there are a variety of themes in each book, and many of them are universal. When I was a teen, I never wanted to read just about girls my age. I was always interested not only in what was happening, but what came next as well. In addition to that, several of the books have a strong family component, which I think many girls can relate to even if they haven't yet had experience with boys or any of the other 
issues that are part of the story. In all truth, though, I think as an author you can't put too much focus on trying to appeal to everyone. I just try to write the story I want to read, and then hope for the best.

TAR: In Just Listen, Annabel finds herself afraid to speak to the classmates she has grown up with, simply because of an act that has been done to her. Do you think this is a typical reaction of teenage girls who find themselves in similar situations?

SD: In my mind, it's more complicated than not wanting to speak to people because of what's happened to her. It's also that she's had conflicts with many of these people

Annabel is afraid of confrontation, which I think is very typical for girls. At the same time, though, there is a lot of shame associated with sexual assault, which makes it very difficult for anyone, and teenagers especially, to be open about it. in the past-her former friends Clarke and Sophie, for instance-that have made it that much harder to be open with them about anything, much less something as big as a sexual assault. Annabel is afraid of confrontation, which I think is very typical for girls. At the same time, though, there is a lot of shame associated with sexual assault, which makes it very difficult for anyone, and teenagers especially, to be open about it.

TAR: It used to be that bullying was considered an issue only among boys. However, it has become more and more apparent that girls participate in a subtler version of bullying. Many of Sophie's actions, as well as those of her followers, reflect this type of bullying. Were you trying to illustrate the effects of these actions while writing about Sophie?

SD: It was necessary to show how Sophie operatesintimidating people, getting revenge on those she believes have wronged her-in order to make it believable that Annabel would be so isolated once they were no longer friends. The fact that Annabel was there when Sophie did these things means that people aren't exactly reaching out when the same thing happens to her. At the same time, I had to show why Sophie was appealing to Annabel in the first place, that she was dynamic and different and opened up this whole new world that hadn't been there before. It's a delicate thing, to show the draw and the subsequent price paid for befriending someone like that. It was actually very similar to what I had to do with Rogerson, the abusive boyfriend, in Dreamland.

TAR: Speaking of Rogerson, many of your other characters have unusual names. Every time you write a new story, you essentially give birth to new people. With so many new people populating your world, how do you come up with the names for all your characters? Have you ever had to change a character's name because it didn't seem to fit the character's personality?

SD: When I'm starting a new book, the narrator's name always comes first. I find them in all kinds of places: Halley from Someone Like You was obviously from the comet, but I've stolen names from people I've met (Colie, from Keeping the Moon, was the name of a girl who came to a book signing) or just heard of (Remy, from This Lullaby, was the first name of a football player I overheard interviewed on the radio). To me, names are crucial: if I pick the right one, at least some of the attributes of that character jump into my head soon after. I think I always pick somewhat unusual names because when I was younger, I always wished my name was more exotic. Now, I love being a Sarah, but then I was so envious of my best friend, whose name is Bianca. I've never changed the name of a narrator, that I can remember, although I have changed other characters' names. Usually it's because it conflicts with another name, or I realize the character has changed, and the name doesn't work for them anymore.

TAR: Honesty and self-confidence seems to be recurring themes within your novel. Is this a conscious decision on your part as you are developing your characters? 
SD: It's not as much a conscious thing as it is the fact that these were things I was struggling with a lot as a teen. It's easier to be confident once you're older, with a lot of experiences under your belt, but in high school everything is happening for the very first time. There's no primer, or flow chart, to show you how to handle every situation, which can lead to a lot of doubt and stress. You only grow confidence and strength by enduring things, and I try to show that with my characters, that they're girls who go up against challenges and come out changed in many ways on the other side.

TAR: Many authors who write stories that deal with issues that young adults experience find themselves approached by their readers. These readers frequently feel thankful that a story similar to their own has been told. Have you ever had any such experiences?

SD: I'm often very overwhelmed by what I hear from my readers. The most emotional responses I've gotten have been via email, through my website. For example, since Just Listen was published in April, I've heard from several people who told me about their own experiences being assaulted, a few of whom had told no one else. I also heard from a lot of girls after Dreamland came out who wanted to tell me about being in abusive relationships. On the one hand, it's amazing that they feel comfortable enough to reach out to me and be so open. At the same time, I do worry about the right way to respond. It's a lot of responsibility. Usually, I encourage them to talk to someone else, their parents, a clergyperson, a counselor or a friend.

TAR: What is the most difficult aspect of the writing process for you?

SD: The first draft is definitely the hardest part for me. When I'm working on a book, I work every day, seven days a week, and it's usually pretty slow going, because I'm very meticulous. I think it's partially because I've learned a lot from writing seven books (that were published: I have about seven more that will never see the light of day). I like to think that I have a better idea now what works and doesn't work for me, although this is

certainly not always the case. (See those seven books, above.) I don't outline, but I do write in order, always, which means that each scene and chapter has to be strong enough to support what comes after it. So I'm often tinkering, and rewriting, trying to get things right, and that takes time.

TAR: You mention that you have several books that won't see the light of day. Do any of the elements or characters reincarnate themselves in your other books? What are your feelings about these unpublished books? Are they as valuable to you as the published ones?

SD: I've definitely used things from books that haven't worked. Dreamland, in particular, came from a novel that was too long and weighty, but had a subplot with Caitlin and Rogerson, although it was much different in its initial incarnation. I put the same amount of work and time into every book, whether it works or not; I'd never start a book if I expected it to fail. So I'm attached to all of them, even the ones that no one but me will ever read. In some ways, I might even learn more from them because I have to figure out what doesn't work. It can be hard to let go. If you read The Truth About Forever, there's a character mentioned at the very beginning named Amy Richmond. I wrote an entire book about Amy, and know everything about her and her story. It ended up not working, so I snuck her into the next one in the hopes that she'd still get out there somehow. And she did.

TAR: Some authors build support networks with other authors to help each other over the rough spots that often come when crafting a story. Do you have other authors that you converse with regularly? Or is there another support network that you rely on?

SD: I'm lucky to have several friends who are writers, which I think can be very helpful. I don't discuss 
the specifics of what I'm working on with anyoneI tend to be very private, the book's like a secret I want to keep for as long as possible-but it's always nice to have someone to commiserate with who really understands, especially when you're stuck or frustrated. Writing is one of those jobs that there's really no right way to do, no manual you can
Writing is one of those jobs that there's really no right way to do, no manual you can buy and follow. You just learn as you go, and sometimes, that learning is hard. buy and follow. You just learn as you go, and sometimes, that learning is hard. It helps to be neurotic, I think, so you're already used to feeling a little crazy every day. I'm fortunate in that I have a great husband and very supportive friends, who at this point just roll their eyes when I say I'm convinced I've lost any talent I ever might have had and am considering a new career path, like, say, working at the CVS or something. They, unlike me, always remember that there's a point in every book when I think I can't go on. And then they tell me to do just that.

TAR: It's great that you have such a support system. Do you ever read fellow authors' novels and provide feedback before they reach the published stage?

SD: I have on occasion, but only with my students, and close friends. It's a very vulnerable thing to show someone an unedited manuscript, and I think you have to trust them very much. I get asked a lot through my website to read manuscripts, but for legal reasons, I just can’t.

TAR: You stated on your web page that you hated being told what you were to write when you were in high school. What advice would you give English teachers about writing instruction?

SD: I understand that it's hard to motivate kids to write, and that in high school, it's crucial to learn how to write argumentatively and craft essays. But writing creatively has its own benefits, as well. I think there's a lot to be said for allowing students to just write, with a minimum of a prompt or no prompt at all. It's not easy, and I know, because I taught Intro to Fiction Writing at UNC-Chapel Hill for seven years. My students were often completely overwhelmed when I'd say, "Write about something that really affected you," or just "write a story." They'd sit there, blank faced. But once they started, something came, and often it surprised them. It's like a different way of thinking about words and your use of them, and I think it can only help all the other ways you write. But that's just my opinion, of course.

TAR: With today's focus in education on high-stakes tests, many English teachers feel that there has been a tendency to neglect writing instruction within schools. As a creative writing teacher at the university level, do you feel that this shift in focus has impacted student writing?

SD: My students had a really hard time breaking the rules they'd been taught about writing. They never wanted to use contractions, for example: I got a lot of "We are going to the store," and "I will take the bus." I kept saying to them, "Real people don't talk like this!” Also, like I said above, they had a hard time just writing without being told very specifically what to write. They didn't want to use first person. Their writing was so clean, but fiction isn't supposed to be clean: it has to be messy, especially in a first draft, when you're just getting it down. Eventually, they learned this. But it did take time.

TAR: To build upon the idea that many secondary English teachers feel forced to neglect writing instruction in order to prepare for reading tests, what do you think about this neglect? Do you think that students are being short-changed in their English instruction? Or do you believe that natural writers will pick up the skills on their own?

SD: I would hope that natural writers are reading enough to be learning on their own, but it's hard to say. There's always been that debate about whether writing can be taught at all, and I believe it can, to a point. You can take what someone writes and show them how to improve it. But there are some 


\section{Just Listen}

by Sarah Dessen

Reviewed by Robyn Seglem

$\mathbf{W}$ hat makes the perfect girl with the perfect family tick? Despite appearances to the contrary, don't ask Annabel Greene. Annabel is the girl that younger girls idolize. A teen model, groomed by her mother from a young age, Annabel's image flashes across television screens and across the stage as she models for Kopf's department store. By all appearances, Annabel has everything a teenage girl can want. But perfection is seldom a reality. Annabel's reality includes Sophie, a volatile girl who Annabel once called best friend, but who now stalks the halls verbally attacking Annabel at every turn of the corner; Annabel's sister Whitney, an ex-model who has returned home from New York to battle a serious eating disorder; and her mother, a woman driven to battle her own depression by pushing upward her daughters' modeling careers, careers that mean more to Annabel's mother than the girls themselves. It's no wonder that Annabel feels she has no one to confide in, to let in on the secret that destroyed her friendship with Sophie and eats away at her soul.

When Annabel meets Owen Armstrong, she is intrigued by the strange boy who appears to be as much an outcast as she has become. At first, she watches him from afar, but in a moment of weakness, when Sophie's cruelty drives her to sickness, it is Owen who reaches out and rescues her. Through Owen, she learns the value of friendship, of listening to oneself, of telling the truth, no matter the costs. Despite these lessons, however, can she find the courage within herself to help others by telling the truth about the event that ended her friendship with Sophie? And can she reach out to her family, helping them heal themselves without sacrificing her own self?

Fans of Sarah Dessen will not be disappointed by Annabel's story. Told from Annabel's point-ofview, Dessen's book has captured the voice of young girls across the country. Unfortunately, today's schools are filled with girls who have been attacked both physically and mentally, and Annabel's story captures the range of emotions this abuse creates. Yet, Annabel's story illustrates the power friendship and trust can have over the healing process. While her journey is not an easy one, the ultimate destination brings her a newfound peace and confidence, teaching her the power of just listening. In an era where many teen issue stories do not have happy endings, this one does, giving girls who can connect to Annabel's situation a belief that there is hope for healing.

Dessen, Sarah. Just Listen. Viking (Penguin Group), 2006, 371 pp. ISBN: 0-670-06105-0. \$17.99. things you either come to naturally, or you don't. I saw this again and again in my classes, where I often had students who were decent writers and worked hard, but never could get that real spark that makes words jump off the page. Then there would be the ones who had that the very first day and wrote something that blew me away. I would hope that students like that would seek out creative writing in college if they weren't able to have it in high school. But you just never know.
TAR: As a daughter of a classicist and a Shakespearian professor, you were obviously well-versed in the value of the classical canon. Today's schools often debate between the philosophy of teaching only the literary canon and teaching young adult literature. What place do you see young adult literature having within schools? What would you say to the critics who label the genre as "brain-candy" with very little literary value? 
SD: Well, of course as a YA writer I'm not going to agree that all fiction for adolescents is mindless. That's a ridiculous assumption. I do think it's important to read the classics, but why can't there be a balance of classic literature and more

I do think it's important to read the classics, but why can't there be a balance of classic literature and more modern voices? The most important thing about reading, to me, is connecting with a story and its characters. It would be great if everyone could do that with Beowulf, but I just don't think it's possible. modern voices? The most important thing about reading, to me, is connecting with a story and its characters. It would be great if everyone could do that with Beowulf, but I just don't think it's possible. However, if you give students something that they can relate to, it can open up an appreciation of reading that they might not find otherwise. My mother is a very intellectual reader, and when I was in high school, she was always dismayed that I preferred Stephen King over the more "literary" books she was hoping to interest me in. "At least you're reading!" she'd sigh, and I was. Not just Stephen King (who I love) but also lots of other things. I loved to read because I'd been allowed to try all kinds of things, and find out what really appealed to me.

TAR: As an English teacher and lover of YA lit, I completely agree that it's important to expose kids to a variety of authors and genres, and I have had great debates with fellow teachers about the ability to teach traditional literary elements with YA novels. In fact, your books do possess these elements, i.e. the symbolism of the glass house in Just Listen. In my own experiences, I frequently find symbolism difficult to pull off in a way that doesn't seem forced. Do you ever have similar problems when developing a symbol within your story or does it come naturally as the story evolves?
SD: One of my writing teachers at UNC, the great Doris Betts, always told us that forced symbolism doesn't work. She said that you have to trust that your story will provide you with the things that you need to make it resonate. (I'm paraphrasing here, of course: Doris would say this much more eloquently.) If you decide a sandwich is a symbol, and plant it with that intention, its purpose will be obvious to the reader and take away from what you're trying to do. The best symbols in my books have been completely unconscious, ones that just come in the course of writing and then later I think, "Oooh! That's good." But doing that requires a lot of faith, and a giving up of control, neither of which is my strong suit when I'm working. I try, though.

TAR: Having had some censorship issues within my own classroom, I have found adults who fear the tough issues that many young adult books, including your own, possess. What are your thoughts about this fear? Would you ever change the way you craft a story because of fears of censorship?

SD: I long ago learned that certain people are not going to like the books I write, and me trying to argue otherwise was about as fruitless as them convincing me to write differently. It's just not happening. Adolescence is a tough time, and I think to write honestly about it, you often have to address dicey issues. When I'm working on a book, I'm not thinking about how someone might be offended by the choices I'm making on the page. It's entirely counterproductive, because you'll never be able to please everyone. Instead, I focus on writing the best book I can. That's all I can do.

TAR: In your on-line journal, you reference several favorite TV shows, and you have had the experience of two of your books being turned into a movie. Have you ever considered moving beyond the female YA audience into screenwriting or perhaps another genre?

SD: I'd like to write a novel with an older narrator, eventually. I mean, a lot has happened to me since 
high school that would be fun to write about. But as long as I keep having good ideas that intrigue me, I'll probably stick to YA as well. For whatever reason, it works for me. As far as a screenplay, I think it would be fun to try sometime. But since that is MUCH more like writing by committee, I have a feeling it might be hard for me. Never say never, though.

TAR: What is it like to have become a celebrity within the community you grew up in? Do you find that people you knew as a child treat you any differently?

SD: I don't consider myself a celebrity at all. Now, if I played forward for the UNC basketball team, THEN
I'd be a big deal here. But there are so many amazing writers, and everyone's known me forever. Occasionally, people recognize my name, or my face, but more often than not they went to high school with me, or know me from my waitressing days. And that's fine with me.

Robyn Seglem is a language arts teacher at Trailridge Middle School, Shawnee Mission, Kansas. She is a codirector of the Flint Hills Writing Project, an affiliate of the National Writing Project. She has been teaching for seven years and is currently working on her Doctorate in Curriculum Instruction from Kansas State University. 